\title{
Strategy for Non-Performing Financing Management in Sharia Banks Based on Economic Sector of Financing
}

\author{
Moch Hadi Santoso, Hermanto Siregar, Dedi Budiman Hakim, Mulya E. Siregar \\ Business School, Bogor Agricultural University, Bogor, Indonesia \\ Email: santosohadi57@gmail.com
}

How to cite this paper: Santoso, M.H., Siregar, H., Hakim, D.B. and Siregar, M.E. (2019) Strategy for Non-Performing Financing Management in Sharia Banks Based on Economic Sector of Financing. Open Journal of Business and Management, 7 , 374-385.

https://doi.org/10.4236/ojbm.2019.72025

Received: August 28, 2018

Accepted: February 10, 2019

Published: February 13, 2019

Copyright $\odot 2019$ by author(s) and Scientific Research Publishing Inc. This work is licensed under the Creative Commons Attribution International License (CC BY 4.0).

http://creativecommons.org/licenses/by/4.0/

\begin{abstract}
This study aims to determine the strategy for non-performing financing management on financing in Islamic banks based on the economic sector of financing. This study was specifically carried out at the BRI Syariah Bank in the period 2010 to 2017, using the Analytical Hierarchy Process (AHP) in determining its handling strategy with the involvement of nine experts as respondents with the background of three people from Islamic bank practitioners, three people from the profession academics or lecturer staff, and three people from the sharia banking authority or regulator. In the formulation of strategies for handling non-performing financing in financing, it is divided into five levels, namely level 1) goal, level 2) economic sector, level 3) factor, level 4) actor, level 5) program. The results showed that the economic sector that needs attention with a high level of importance is the trade, restaurant and hotel sector with a weight of 0.197 , followed by the construction sector with a weight of 0.189 and the industrial sector with a weight of 0.168 . An important factor that needs attention regarding non-performing financing is the handling of NPF with a weight of 0.243 , followed by bank rating of the bank-a risk profile with a weight of 0.217 and Indonesia's economic growth with a weight of 0.148 . The actors who play an important role in handling non-performing financing are directors with a weight of 0.300 followed by work units with a weight of 0.178 and economic conditions with a weight of 0.144 . The most important non-performing financing management program is intensive collection with a weight of 0.340 , then the restructuring with a weight of 0.312 and collateral sales with a weight of 0.151 .
\end{abstract}

\section{Keywords}

Analytical Hierarchy Process, Financing Contract, Non Performing Financing, Sharia Bank 


\section{Introduction}

\section{Background}

Sharia banking as one of the preferred banking system in Indonesia has a very promising growth potential in the future. Indonesia is a country that has the largest number of Muslims in the world with more than $80 \%$ of the composition of people in Indonesia are Muslims. The growth potential of sharia banking shows its development since the founding of Bank Muamalat in 1991 until today there have been thirteen Sharia Commercial Banks. Islamic banking has a 33.7\% Compounded Annual Growth Rate (CAGR) from 2006 to 2014. This growth is relatively much higher than the conventional Indonesian banking CAGR of $16.2 \%$ in the same period (source: statistic of sharia banking, OJK). The comparison of the development of sharia banking to conventional banking in Indonesia during the period 2014 to 2016 can be seen in Table 1. During 2014-2016, the growth of Islamic banking was twice as large as that of conventional banking.

Sharia banking which is part of the national banking is also not spared from the impact of declining economic conditions both regionally and nationally. This can be seen in Table 2. Indicating that there is indeed a slowing growth in

Table 1. Bank industries development in Indonesia (in Miliar Rupiah).

\begin{tabular}{|c|c|c|c|c|c|c|}
\hline \multirow{2}{*}{ NATIONAL BANKING } & \multirow{2}{*}{ Des-14 } & \multirow{2}{*}{ Des-15 } & \multirow{2}{*}{ Des-16 } & Growth & \multirow{2}{*}{ Des-17 } & Growth \\
\hline & & & & Des'15-Des'16 & & Des'16-Des'17 \\
\hline ASSET & 5.615 .150 & 6.095 .908 & 6.729 .799 & $10.40 \%$ & 7.387 .144 & $9.77 \%$ \\
\hline FINANCING & 5.468 .910 & 4.057 .904 & 4.377 .195 & $7.87 \%$ & 4.737 .972 & $8.24 \%$ \\
\hline THIRD-PARTY FUNDS & 4.594 .876 & 4.413 .056 & 4.836 .758 & $9.60 \%$ & 5.289 .209 & $9.35 \%$ \\
\hline EARNING AFTER TAX & 143.591 & 133.521 & 137.467 & $2.96 \%$ & 166.887 & $21.40 \%$ \\
\hline \multirow{2}{*}{ SHARIAH BANKING } & \multirow{2}{*}{ Des-14 } & \multirow{2}{*}{ Des-15 } & \multirow{2}{*}{ Des-16 } & Growth & \multirow{2}{*}{ Des-17 } & Growth \\
\hline & & & & Des'15-Des'16 & & Des'16-Des'17 \\
\hline ASSET & 272.343 & 296.262 & 356.504 & $20.33 \%$ & 424.181 & $18.98 \%$ \\
\hline FINANCING & 199.33 & 212.996 & 248.007 & $16.44 \%$ & 285.785 & $15.23 \%$ \\
\hline THIRD-PARTY FUNDS & 217.858 & 231.175 & 279.335 & $20.83 \%$ & 334.719 & $19.83 \%$ \\
\hline EARNING AFTER TAX & 2.049 & 2.301 & 2.949 & $28.13 \%$ & 4.417 & $49.79 \%$ \\
\hline
\end{tabular}

(Source: Statistics of Sharia Banking, FSA).

Table 2. Sharia banking financial ratios (\%).

\begin{tabular}{cccccccc}
\hline YEAR & 2011 & 2012 & 2013 & 2014 & 2015 & 2016 & Jun-17 \\
\hline CAR & 16.63 & 14.13 & 14.42 & 15.74 & 15.02 & 16.63 & 16.42 \\
ROA & 1.79 & 2.14 & 2.00 & 0.41 & 0.49 & 0.63 & 1.1 \\
NPF & 2.52 & 2.22 & 2.62 & 4.95 & 4.84 & 4.42 & 4.47 \\
FDR & 88.94 & 100 & 100.32 & 86.66 & 88.03 & 85.99 & 82.69 \\
BOPO & 78.41 & 74.75 & 78.21 & 96.97 & 97.01 & 96.22 & 90.98
\end{tabular}

(Source: Statistics of Sharia Banking, FSA). 
financing for national sharia banking. Evidently the trend shows a decline in financing growth, which in mid-2017 only reached $6.09 \%$. The low growth of financing during the year 2017 was compared in 2016, resulting in a decline in the growth of sharia banking assets. The declining growth of Islamic banking assets contributes to the increase in Return on Assets in sharia banking. This can be seen in Table 2 on trend value Return on Asset ratio has increased from $0.63 \%$ in 2016 to $1.10 \%$ in June of 2017 .

Along with the declining growth of asset, financing, DPK and the profit of sharia banking nationally, it is also seen that sharia banking has increased nonperforming financing (NPF). The NPF increase is quite high in the period of 2013 from $2.62 \%$ to $4.95 \%$ in 2014. In June 2017 position, sharia banking NPF is still quite high at $4.47 \%$. This is due to the slowing down of economic conditions due to the decline in commodity prices during 2015 to 2016, which has resulted in an increase in NPF in sharia banking.

Financing means the provision of monery or equivalent claims based on an agrement between the bank and other parties requiring the party financed to refund the money or the bill after a certain period of time in return or profit sharing. In Islamic Banks, Non-performing financing frequently occured because of customers default in committing their payment which affected to Bank's loss. According to Mahmoeddin (2004) [1], non-performing financing attitudes indications were determined by account attitudes, financial statement attitudes, business activities attitudes, customer attitudes and macro economic attitudes. Furthermore, non-performing financing factors had driven by three elements which are Bank itself (creditor), debtors and other parties. From those perspectives, it can be concluded that many variables influence financing ratios or non-performing financing in financial institution. Figure 1 below showing Islamic Bank NPF movement and Nett NPF period of June 2014 untuk December 2016.

Bank BRI Syariah as one part of Islamic banking is also experiencing problems that is the decline in the quality of financing that the trend can be seen in Figure 2.

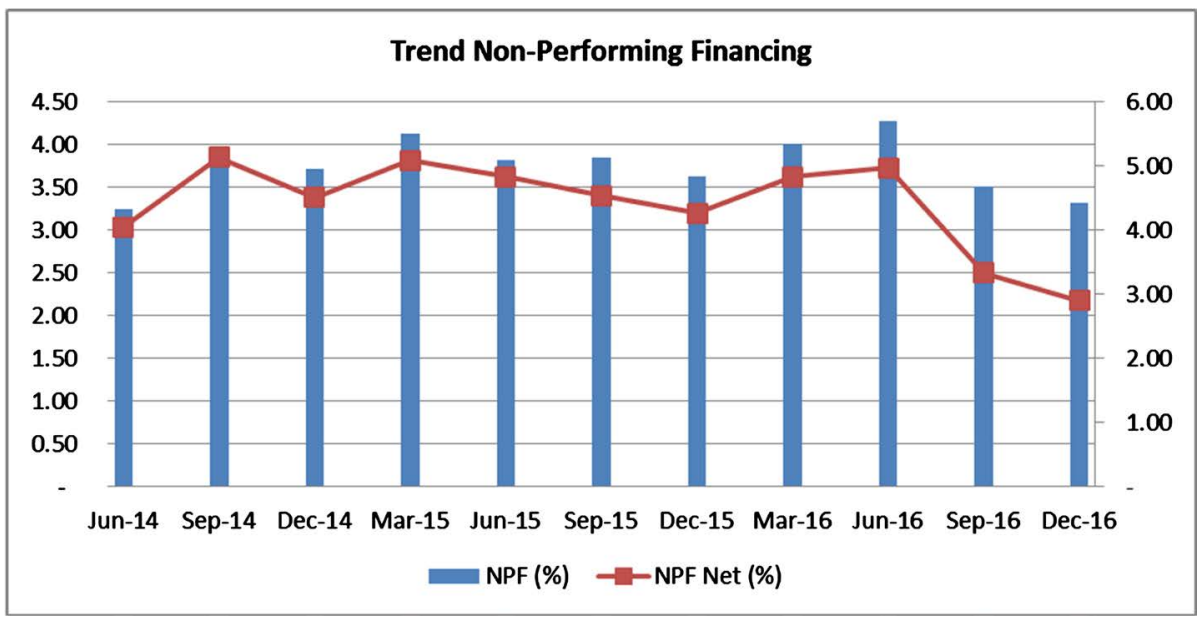

Source: Financial Services Authority/FSA/OJK (2017).

Figure 1. Islamic Bank NPF and Nett NPF trend in Indonesia. 


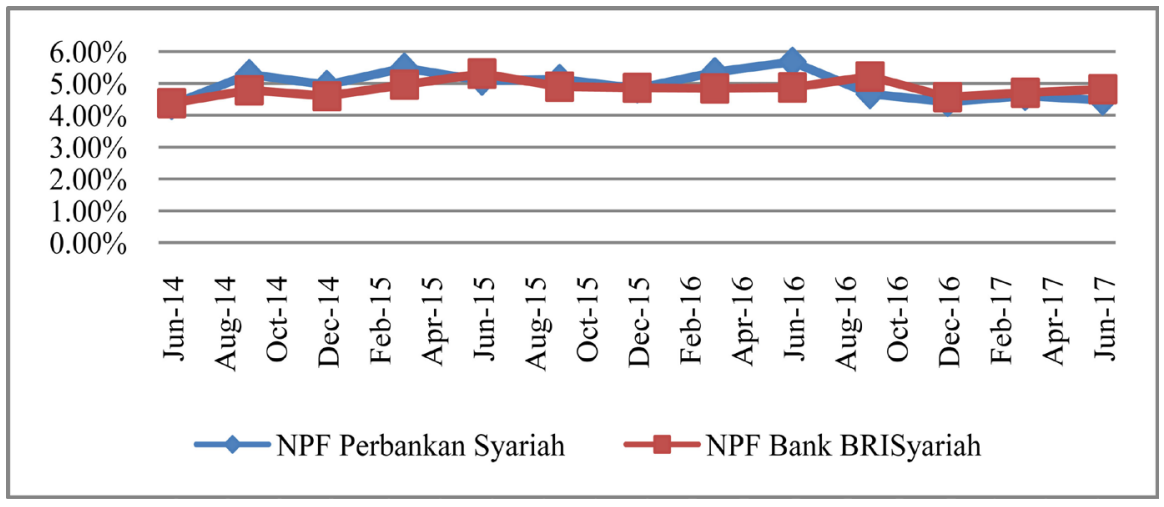

Source: Financial services authority/FSA/OJK (2017).

Figure 2. Islamic Bank NPF and Bank BRI Syariah NPF Trend.

It is seen that the value of non-performing financing ratio of Bank BRI Syariah is even above the average ratio of problematic financing of national sharia banking.

Problem formulation research based on the above descriptives is how is strategy for non performing financing management in sharia banks based on economic sector of financing. Research objectives are formulate strategy for non performing financing management in sharia banks based on economic sector of financing consist of 1) agriculture, hunting and agricultural facilities, 2) industrial, 3) electricity, gas and water, 4) construction, 5) trade, restaurants and hotels, 6) transport, warehousing and communication, during period of 2010-2017.

\section{Literature Review}

Ismal (2014) [2], examines the level of risk and optimal profit sharing in the Islamic banking portfolio. Based on the research conducted: 1) Indonesian Islamic banking allocates most of the funds for Murabahah and Mudharabah Financing, 2) Murabahah and mudharabah have the highest rate of return among other instruments while the most risky instruments are Mudharabah financing, 3) efficient curves of portfolio frontiers built to find the most efficient location combination of Mudharabah and Murabahah financing. Bakshi (2015) [3] conducted a study of factors that affect losses in financing at banks in India. The results showed that net interest margin (NIM) and capital adequacy ratio (CAR) had a negative influence on non-performing financing and lending to sensitive sectors had a positive effect on non-performing financing. Ismail, Ghafar and Adelina (2007) [4] conveyed the composition of the bank's loan portfolio and disclosure of loan loss provisions, empirical evidence from Bank Malaysia. It is found that the allowance for loan losses has a positive effect on non-performing loans, loss on allowance loans and write-offs. The performance of each economic sector must also be considered because of the different default risks.

Research on the factors affecting non-performing loans was also carried out in Europe, namely by Skarica, Bruna (2013) [5], it is known that the growth of real gross domestic product is the main driver of the increase in NPLs over the last 5 years in European countries. The slowdown in economic activity has greatly af- 
fected the financial stability of the region, and an increase in the inflation rate is expected to cause NPL growth. The solution to the problem of NPL is a proactive and cooperative approach from creditors, debtors and regulatory systems. Even in Tunisia, Messai and Fathi (2013) [6] research related to macro and micro economic influences, with the results of GDP growth rates, profitability of bank assets negatively affect non-performing loans, and unemployment rates, loan loss reserves to total loans and interest rates Real has a positive effect on non-performing loans.

One way that can be done in determining the strategy is to set priorities that must be done. Selection of these priorities can be a part of decision making. The tools that can be used are using the Analytical Hierarchy Process (AHP). Analytic Hierarchy Process (AHP) is one method to help decision makers in making decisions in accordance with the criteria or requirements that have been determined, and the criteria for decision making are various criteria. The Analytical Hierarchy Process (AHP) method is multi-criteria because it uses many criteria in the preparation of a priority decision support system. Besides its multi-criteria nature, the AHP method is also based on a logical and structured process, because the prioritization is carried out using logical and structured procedures. The activity is carried out by experts who are representatives who make their priorities. The Analytic Hierarchy Process method is one method of decision making that can help human thinking. This method was developed by Thomas L. Saaty in the early 1970s. The process of thinking this method is to form a numerical score to develop alternative ways of making decisions where the decision is matched with the criteria of the decision maker (Faaiz, 2009) [7].

The decision-making process equipment on the main Analytic hierarchy process method is a functional hierarchy with the main input of human opinion. With hierarchies, unstructured problems can be solved into groups which are then arranged into a hierarchical form. In elaborating the hierarchy of objectives, there is no definite guideline on how decision makers describe it as a lower goal. Decision-makers determine the elaboration of these goals stop and pay attention to the advantages and disadvantages that are obtained if the goal is further detailed. The following are some things that must be considered in elaborating the hierarchy of objectives, namely:

1) At the time of elaboration of the objectives into the sub-objectives must pay attention to each objective that will be included in a more detailed sub-objective.

2) Even though the first thing can be fulfilled, it also needs to avoid too much division.

3) Therefore, before setting goals must be able to describe the hierarchy to the lowest destination by testing it.

The Analytic Hierarchy Process (AHP) method is often used as a problem-solving method compared to other methods. The following are some of the advantages of using the AHP method (according to Suryadi and Ramdhani, 1998) [8]:

1) Structured hierarchy, as a result of the selected criteria, to the deepest sub- 
criteria.

2) Taking into account the validity up to the tolerance limit of inconsistencies of various criteria and alternative ways chosen by decision makers.

3) Take into account the durability and results of the analysis of decision makers.

AHP method takes into account the level of validity up to the tolerance limit of inconsistency with various criteria and alternative ways chosen by decision makers, AHP method also has the ability to solve multi-criteria problems based on the comparison of preferences of each element in the hierarchy, so that comprehensive.

\section{Analysis Method}

In solving problems with Analytic Hierarchy Process (AHP) there are several principles that must be understood which are the first principle is decomposition (create hierarchy). In decomposition arranging the hierarchy must determine the goals through the criteria used to assess the alternatives. Each criterion sometimes has sub-criteria below which have their respective intensity values. Second principle is comparative judgment (assessment of criteria and alternatives), synthesis of priority (determining priorities). Criteria and alternatives are carried out by pairwise comparisons. According to Saaty (1996) [9], for various problems, a scale of 1 to 9 is the scale used in the assessment. Third principle is determining the priority of each criterion is used as the weight of these criteria in decision making. The Analytical Hierarch Process (AHP) method performs a priority analysis of each criterion with a pairwise comparison method between two elements so that all existing elements will be included in the comparison. And fourth principle is logical Consistency (logical consistency). Consistency has two meanings. The first is that similar objects can be grouped according to their type. The second is concerning the level of relations between objects based on certain criteria (Kosasi, Sandy. 2002) [10].

To solve a problem using the Analytical Hierachy Process method, the following steps are needed:

1) Define problems and determine goals.

2) Arrange the problem into a hierarchical structure so that complex problems can be reviewed in terms of detail and structure.

3) Set priorities for each element of the problem.

4) Testing consistency on comparisons between elements obtained at each level of the hierarchy.

Calculation of Analytical Hierarchy Process, Saaty (1999) [11] explains that the elements in each row of a square matrix are the result of pairwise comparisons. Each pairwise comparison matrix is searched for its eigenvector to get local priority. The pairwise comparison scale is based on the fundamental Analytical Hierarchy Process values with a weighting of 1 for the same, up to 9 for very important. Based on the arrangement of pairwise comparison matrices, a num- 
ber of elements in the element within the existing level are generated. Deviations from consistency are expressed in the consistency index obtained from the formula:

$$
\begin{gathered}
\mathrm{CI}=\left(\lambda_{\max }\right) /(n-1) \\
\mathrm{CR}=\mathrm{CI} / \mathrm{RI} \\
\lambda_{\max }=\text { Add the results to the number of elements available } \\
n=\text { Number of elements }
\end{gathered}
$$

Consistency index (C1), a random matrix with a research scale of 1 to 9 , along with its inverse as a random index (R1). Based on the Saaty calculation with 500 samples, if numerical judgment is taken randomly from a scale of $1 / 9,1 / 8, \ldots$, $1,2, \cdots, 9$ the average consistency for different size matrices will be obtained. The comparison between $\mathrm{C} 1$ and $\mathrm{R} 1$ for a matrix is defined as the consistency ratio (CR). For the Analytical Hierarchy Process the comparison matrix can be accepted if the consistency value is not more than 0.1 or equal to 0.1 .

\section{Results \& Discussion}

\subsection{Design Hierarchy}

The following is the design of the AHP hierarchy structure for NPF handling strategies based on the economic sector with factors that significantly influence the NPF consisting of Bank Rating-Risk Profile, Bank Rating-Profitability, Net Income Margin (NIM), Financing Growth, Economic Growth, NPF Management, and Benchmark Interest Rate (Figure 3).

Furthermore, each expert will provide an assessment of the NPF BRISyariah

\section{DESIGN HIERARCHY STRUCTURE FOR NPF BASED ON ECONOMIC SECTOR}

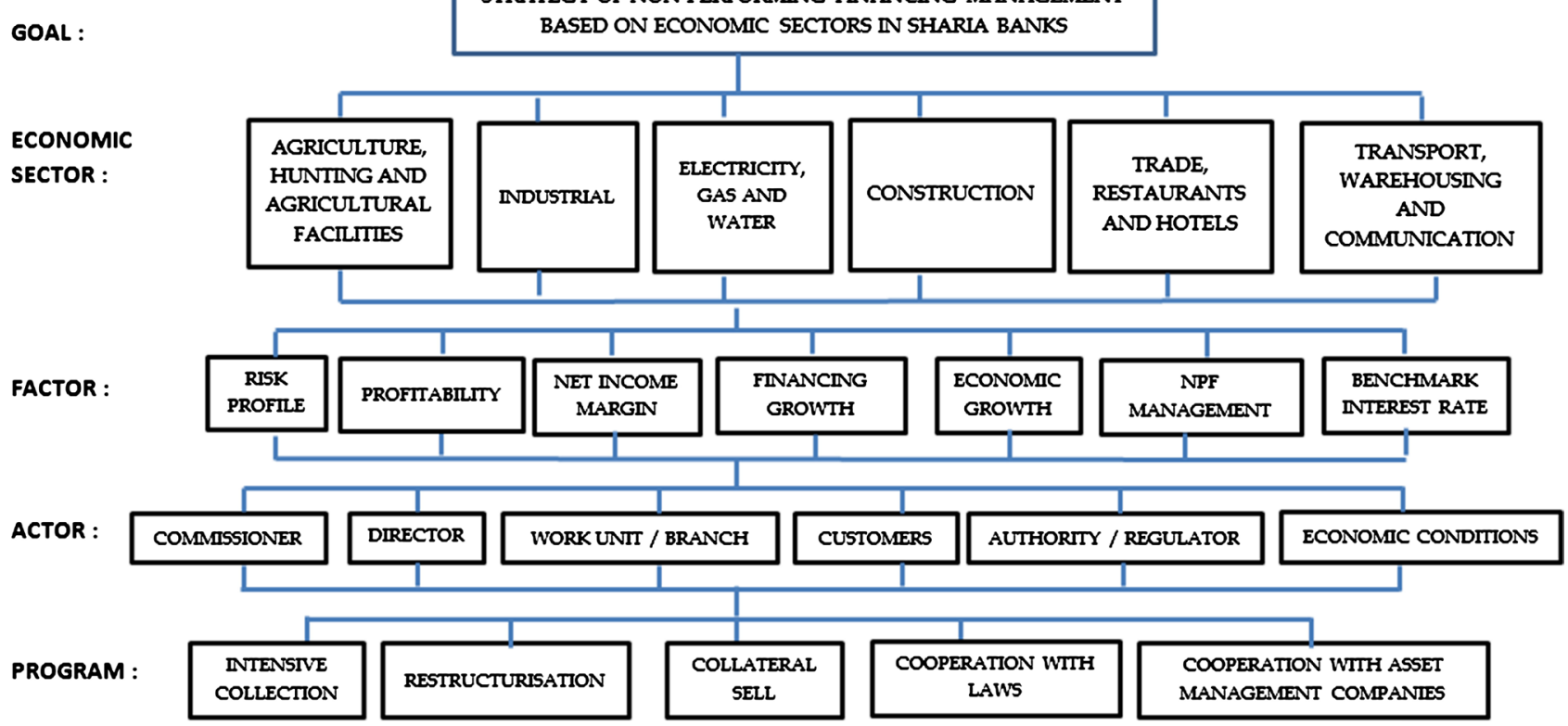

Figure 3. AHP's hierarchy structure for NPF management strategies based on the economic sector. 
management strategy based on the economic sector. For handling strategies NPF BRISyariah based on the expert economic sector will provide an assessment of the economic sector, factors, actors and programs that have a high weight and importance and need attention.

\subsection{The Weight and Priority of the Management Strategy for NPF are Based on the Economic Sector}

In the NPF managing strategy based on the economic sector, the sectors that need attention due to their high weight and importance are trade, restaurants and hotels (weighting 19.7\%) and construction (weighting 18.9\%). Both of these economic sectors, especially the trade, restaurant and hotel sectors, are the economic sectors that are mostly funded by BRISyariah (20.3\%) and Islamic Commercial Banks (11.3\%) after the household economic sector (residential and other household appliances ) In this sector the distribution starts from financing the micro, SME and commercial business segments to individuals and business entities. Likewise, the economic sector of construction was channeled by BRISyariah by $10.5 \%$ of all total financing and $7.42 \%$ by Sharia Commercial Banks. Along with the high distribution of financing in both sectors, the two sectors have an important role. In general both the BRIS and Sharia Banks, the NPF in the economic sector of trade, restaurants and hotels has a greater percentage compared to the economic sector of construction.

For factors that have an important role and a large weight in managing NPF based on the economic sector are the management of NPF (weighting 24.3\%) and the level of bank health-risk profile (weight 21.7\%). Along with the diverse economic sectors funded by BRISyariah and Islamic Commercial Banks, a different treatment is needed from one another. In the trade sector, which has the greatest importance or weight, a pattern of handling NPF is different compared to other sectors. In this sector a strict and periodic monitoring approach is required both daily, weekly and monthly. This is done considering the business patterns that occur indicate income and costs that always need to be monitored. Different from the pattern of financing in the construction economy sector, in this sector generally the disbursed financing is used for construction work or completion of development work. In this sector, the managing of NPF is required in the form of monitoring the completion of the work or transferring unresolved work to third parties who have the capability. In distributing financing to these two sectors also requires analysis and evaluation of different risk profiles. Understanding the risk profile measures of the two sectors is a determining factor affecting NPF. The forms of trade and construction financing that will be received can affect the NPF.

Similar to the managing NPF strategy based on business segments and financing agreements, the NPF management strategy is based on the economic sector, actors who have an important role and a large weight are directors (weighting 30.0\%) and work units (weighting 17.8\%). The managing of NPF is based on the financing agreement, requires the support of the board of directors 
and is carried out by the work unit. The decision to handle NPF between the two sectors is also different. In dealing with non-performing financing in the trade sector, analysis and evaluation are needed to determine whether the businesses owned now have the ability to pay. Likewise with the construction sector, because generally the financing of this sector is project based, a scenario or solution is needed to ensure that the projections can be completed by the customer who gets the job or project. Considering that financing in the economic sector is dominated by the two sectors, in conducting financing analysis and evaluation, demanding an evaluation of the beginning and managing of the NPF for financing that has been problematic requires strong collaboration between directors and work units. In general, the work unit will submit an application for the proposed managing of problematic financing, in order to obtain approval from the board of directors. For what has been decided by the directors then carried out by the work unit for further monitoring on a regular basis.

The NPF managing program is based on the economic sector in general with the handling of NPF based on business segments and financing agreements. Intensive collection efforts (weighting 34.0\%) and restructuring (weighting 31.2\%) are important and can be pursued. For efforts to deal with problematic financing or NPF, intensive billing measures always need to be done both for the two main sectors that have a high level of importance and weight as well as for other economic sectors. The NPF management strategy in the form of restructuring is adjusted to the nature or characteristics of each economic sector. Especially for the economic sectors of trade, hotels and restaurants, the forms that occur in restructuring in general are rescheduled or extended. This is in accordance with the use of financing facilities provided in the form of purchase of working capital goods or investment in business support equipment. If the customer has difficulty returning the obligation, then the restructuring in the form of a contract change can also be done as an effort to handle the NPF. As for financing customers in the construction sector, in general in the form of development investments or certain jobs with contracts commonly used are mudharabah/musyarakah. If there is a decrease in the ability to pay or a decrease in the quality of financing, then a rare restructuring is done is to change the contract from mudaraba to musharaka or vice versa. In addition, it can also be in the form of reconditioning in the form of postponement of principal payments up to a certain time limit.

\subsection{Priority of NPF Management Strategies Based on Economic Sector of Financing}

The results of the determination of the NPF management strategy based on economic sector provide results that the actors who play a role in the handling of NPF are directors and work units and authorities/regulators. And the programs that can be carried out are intensive collection, restructuring and collateral sales. This information can be an important matter in determining managerial steps to be taken in handling NPF both in BRISyariah and in Islamic Commercial Banks. The work unit as a party that deals directly with customers is the first factor that 
needs to monitor the possibility of a decline in the quality of customer financing. The work that can be done by the work unit is certainly in the form of intensive collection using various approaches that can be done well in accordance with applicable regulations. If the collection efforts experience problems, where prospective customers experience a decrease in payment ability due to changes in the business cycle and other business factors, it must be analyzed and evaluated in depth. The managerial implication demanded on this matter is that BRISyariah and other Sharia Commercial Banks, in this case the directors, must be able to provide direction or guidance in the form of policies on how to monitor the payment of customer obligations, what tools are used to carry out such monitoring. Furthermore, it is also necessary to provide or provide directives or instructions in the form of policies on how to conduct analysis and evaluation of the customer's ability.

The role of the board of directors is important, considering that the policy that will be carried out by the work unit must get the approval of the directors as management who run the bank's operations. An experience and competency from the board of directors is needed through the decision given to be able to provide direction or guidance for the work unit to handle the NPF that occurs. The Board of Directors is required to be able to provide solutions for efforts to handle NPF that occur. In addition, directors are also expected to always support the work unit in every step taken. And of course the directors also monitor the implementation of the NPF handling that is carried out by the work unit. These things provide an illustration that collaboration between directors and work units is important in making efforts to handle NPF.

Islamic banking which is part of national banking is also not free from the presence of authorities or regulators that govern governance. The presence of authorities in handling NPF in this matter is also important. Authorities can provide a policy or provision that regulates how banks take steps or efforts to handle NPF. Some things that can be done include relaxation or relief in the application of policies. This can be done if the macro economic conditions that occur give a big impact on the decline in financing quality that occurs in the banking industry. The role of authority is also important by providing policies or rules on how Islamic banks collect collateral, restructuring and selling. The rules issued will provide direction for banks in acting so as not to violate existing provisions.

In handling problematic financing that occurs, the first step is to collect. This is part of identifying the problems faced by customers. From the collection, it can be seen whether the customer has the willingness and ability to pay for his obligations. Managerial implications arising from the collection of billing are the mapping done in each collection. Billing is not only solely to collect customer obligations, but also to identify problems that occur to customers. What causes the customer to experience delays in payment of obligations. The next step after it is known that there is a decrease in the ability to pay, the restructuring is one of the ways to handle NPF. The restructuring that can be done can be in the 
form of rescheduling, reconditioning and restructuring. These three steps can be done separately or at once or together. The most important thing that needs to be done is that in choosing the restructuring effort must be in accordance with the capabilities and conditions that occur to the customer. Proper selection of restructuring can be a way to improve the NPF conditions that occur. Customers can get relaxation or relief in fulfilling their obligations for restructuring. So that the most important managerial aspect of restructuring is the accuracy in providing restructuring which is supported by careful analysis and evaluation.

\section{Conclusion}

This study aims to formulate strategy for non performing financing management in sharia banks based on economic sector of financing in Bank BRI Syariah. The results showed that the economic sector that needs attention with a high level of importance is the trade, restaurant and hotel sector with a weight of 0.197 , followed by the construction sector with a weight of 0.189 and the industrial sector with a weight of 0.168 . An important factor that needs attention regarding non-performing financing is the handling of NPF with a weight of 0.243 , followed by bank rating of the bank-a risk profile with a weight of 0.217 and Indonesia's economic growth with a weight of 0.148 . The actors who play an important role in handling non-performing financing are directors with a weight of 0.300 followed by work units with a weight of 0.178 and economic conditions with a weight of 0.144 . The most important non-performing financing management program is intensive collection with a weight of 0.340 , then the restructuring with a weight of 0.312 and collateral sales with a weight of 0.151 .

\section{Conflicts of Interest}

The authors declare no conflicts of interest regarding the publication of this paper.

\section{References}

[1] Mahmoeddin (2004) Tracking Non Performing Loans. Pustaka Sinar Harapan, Jakarta.

[2] Ismal, R. (2014) An Optimal Risk-Return Portfolio of Islamic Banks. Humanomics, 30. https://doi.org/10.1108/H-08-2013-0055

[3] Bakshi, S.D.A. (2015) Determinant of Loan Losses of Indian Banks: A Panel Study. Journal of Asia Business Studies, 9.

[4] Ismail, A.G. and Lay, A.T.B. (2002) Bank Loan Portfolio Composition and the Disclosure of Loan Loss Provisions: Empirical Evidence from Malaysian Banks. Asian Review of Accounting, 10, 147-162. https://doi.org/10.1108/eb060754

[5] Skarica, B. (2013) Determinants of Non-Performing Loans in Central and Eastern European Countries. Financial Theory and Practice, 38, 37-59. https://doi.org/10.3326/fintp.38.1.2

[6] Messai, A.S. and Jouini, F. (2013) Micro and Macro Determinants of Non-Performing Loans. International Journal of Economics and Financial Issues, 3, 852-860.

[7] Faaiz, I.I. (2009) Use of AHP (Analythical Hierarchy Process) in Evaluation of Fi- 
nancing Implementation Based on Principal Financing Analysis at PT BPRS Amanah Ummah. Al-Iqtishad Journal, 1.

[8] Suryadi, K. and Ramdhani, A. (1998) Decision Support System. Teenagers Rosdakarya, Bandung.

[9] Saaty, T.L. (1996) Decision Making with Dependence and Feedback the Analytic Network Process. RWS Publications, Pittsburgh.

[10] Kosasi, S. (2002) Decision Support System (Decision Support System). College of Information and Computer Management, Pontianak.

[11] Saaty, T.L. (1999) Fundamentals of the Analytic Network Process. ISAHP. 